\title{
Utilizing Concept of Vegetation Freeboard Equivalence in River Restoration
}

\author{
Jong-Seok Lee* \\ Department of Civil Engineering \\ Hanbat National University, Daejeon 301-719, Korea \\ Pierre Y. Julien \\ Department of Civil and Environmental \\ Colorado State University, Fort Collins, CO 80523, USA
}

\begin{abstract}
The concept of vegetation freeboard equivalence (VFE) is presented from the comparison between the rise in stage with/without vegetation and the freeboard height under design discharge conditions. In South Korea, the freeboard height of large, medium and small rivers is defined as a function of river discharge. Two models are used for this analysis of flood stage with and without vegetation: the 1-D model HEC-RAS and the 2-D model RMA-2. Both models are applied to three river study sites of the Geum River in South Korea as representative sites for a large, a medium and a small river. The analysis shows that without vegetation, both models provide comparable results and the calculated results are in very good agreement with the design configuration. The vegetation effects on the medium river are less significant, and the freeboard is adequate to contain the rise in stage from the added floodplain vegetation in large rivers. The concept of vegetation freeboard equivalence is therefore useful for the analysis of flood river stages after the restoration of channels with increased floodplain vegetation.
\end{abstract}

Keywords: Vegetation Freeboard Equivalence (VFE); River Restoration; Stream Rehabilitation; Levee Design; Flood Control

\section{INTRODUCTION}

South Korean rivers exhibited near natural conditions before 1960. Since then, the rapid growth through demographic expansion, urbanization and industrialization triggered significant changes with levee construction for flood control and disaster prevention. Several small rivers have been subjected to major transformations, deviations and closures to leave space for roads, parking lots and urban development. The more recent emphasis on river restoration underlines the need to reanalyze flood stages on vegetated floodplains. The concept of public river garden has been developed with an increasing concern to protect the river environment. As a result, some low flow channels have enabled public access and activities on river flood plains with significant upgrades in stream ecology, riparian vegetation and river environment [16]. River management in recent years has also been changed to imitate natural river conditions with stream ecology concepts including increased vegetation to maintain aquatic habitat and channel restoration [22]. The addition of vegetation in conveyance channels is expected to raise the water level at a given flood discharge. The evaluation of the effects of vegetation on the hydraulic stability of levees and on irrigation maintenance

\footnotetext{
* Corresponding author,Email: ljs96@hanbat.ac.kr Manuscript received Jul. 06, 2012; revised Sep 3, 2012; accepted Sep 13, 2012
}

countermeasures needed to be conducted by hydraulic engineers to determine the effects of adding vegetation on river stages at a given discharge [17]. The increased flood stage from floodplain vegetation therefore needs to be carefully evaluated in river restoration projects.

Some of the early investigations of the effects of vegetation on resistance to flow include Chow [7] and Barnes [2]. The effects of vegetation strips, artificial roughness elements and the biomechanical properties of vegetative channel linings could be studied further with the pioneer contributions of Kouwen and Li [14]. Darby [8] also examined the effect of riparian vegetation of flow resistance and flood potential. $\mathrm{Wu}$ et al. [29] also studied flow resistance of grass-lined channel banks and the variation in roughness coefficients for vegetation.

In South Korea, studies include the hydraulic resistance in vegetated in open channel flows by Woo et al. [28], the prediction of stage in a stream with vegetation on the floodplain by Choi and Shin [6], the changes in the downstream hydraulic geometry of the Hwang River below Hapcheon Dam by Shin and Julien [21].

This paper aims at the quantification of flood stages with and without floodplain vegetation. The new concept of vegetation freeboard equivalence (VFE) is introduced and developed in this paper as shown in Fig. 1. The concept hinges on finding the rise in water surface elevation due to the increase in vegetation density, and to compare this quantity with the freeboard height of the designed levees. Three case studies 
representing large, medium and small rivers in South Korea have been selected to illustrate the applicability of the proposed new concept. This article also compares simulation results from both 1-D and 2-D models like HEC-RAS and RMA-2. The applications lead to an evaluation of the proposed new $V F E$ criterion for the analysis of restoration of leveed river systems.

\section{THEORETICAL BACKGROUND}

\subsection{Vegetation Freeboard Equivalence}

The concept of vegetation freeboard equivalence $(V F E)$ is a measure of the rise in water surface elevation due to the vegetation increase in comparison to the freeboard height. Per the definition sketch in Fig. 1, the relationship can be defined as

$$
V F E=\frac{H_{v e g}-H_{\text {des }}}{H_{F B}}
$$

Accordingly, the water level with vegetation would simply overtop the levee when $V F E>100 \%$.

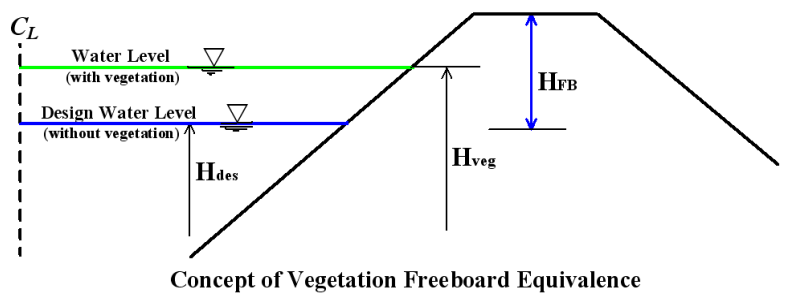

Fig. 1. Concept of Vegetation Freeboard Equivalence (VFE).

By analogy, a Vegetation Safety Factor $S F_{V}$ can be defined as $S F_{V}=1-V F E$, or

$$
S F_{V}=1-V F E=1-\frac{H_{v e g}-H_{d e s}}{H_{F B}}
$$

where $H_{\text {des }}$ is the design flood stage (m) determined as the reference stage corresponding to the design discharge from the flood frequency analysis, $H_{v e g}$ is the calculated flood stage with vegetation $(\mathrm{m})$ calculated using the numerical models, $H_{F B}$ is the levee freeboard height $(\mathrm{m})$ determined by the River Design Criterion shown as Table 1 [15]. Consequently, the vegetation effect would overtop the levee when $V F E>1$ or $S F_{V}<0$. The recommended criteria on the need to raise the levees in the perspective of increased vegetation are proposed in Table 2 . The criteria are based on the analysis of the water levels from the 1-D and 2-D computer models with vegetation presented in this study.

Table 1. Levee Freeboard Height for Design Flood Discharge in South Korea

\begin{tabular}{c|c|c|c}
\hline $\begin{array}{c}\text { Design flood } \\
\text { discharge } \\
Q_{D}\left(\mathrm{~m}^{3} / \mathrm{s}\right)\end{array}$ & $\begin{array}{c}\text { Bank } \\
\text { freeboard } \\
H_{F B}(\mathrm{~m})\end{array}$ & $\begin{array}{c}\text { Design flood discharge } \\
Q_{D}\left(\mathrm{~m}^{3} / \mathrm{s}\right)\end{array}$ & $\begin{array}{c}\text { Bank } \\
\text { freeboard } \\
H_{F B}(\mathrm{~m})\end{array}$ \\
\hline$Q_{D} \geq 200$ & $H_{F B} \geq 0.6$ & $2,000 \leq Q_{D}<5,000$ & $H_{F B} \geq 1.2$ \\
\hline $200 \leq Q_{D}<500$ & $H_{F B} \geq 0.8$ & $5,000 \leq Q_{D}<10,000$ & $H_{F B} \geq 1.5$ \\
\hline $500 \leq Q_{D}<2,000$ & $H_{F B} \geq 1.0$ & $Q_{D}>10,000$ & $H_{F B} \geq 2.0$ \\
\hline
\end{tabular}

Table 2. Recommended Criteria for the Effect of Vegetation on Levees

\begin{tabular}{c|c|c}
\hline$S F_{V}(\%)$ & $\begin{array}{c}\text { Vegetation effect on } \\
\text { water levels }\end{array}$ & Recommended action \\
\hline$S F_{V}>100$ & Low & Maintenance \\
\hline $50<S F_{V} \leq 100$ & Moderate & Low priority to raise the levees \\
\hline $0<S F_{V} \leq 50$ & High & High priority to raise the levees $\bullet$ \\
\hline$S F_{V} \leq 0$ & $\begin{array}{l}\text { Excessive - Water overflows the levees at the design discharge } \\
\bullet \bullet \bullet\end{array}$ \\
\hline
\end{tabular}

\subsection{Flow Resistance}

Frictional resistance to flow in open-channels without vegetation is associated with shear stress along the boundary. The bed shear stress $\tau_{0}$ is applied at the interface between water flow and the wetted perimeter $P$. It is defined as $\tau_{0}=\gamma R S_{f}$, where $\gamma$ is the specific weight of water, $R$ is the hydraulic radius, and $S_{f}$ is the friction slope, respectively. The evaluation of frictional resistance is based on the assumed proportionality between boundary shear stress and square of average velocity for a single coefficient of resistance. The shear stress is also proportional to the square of the shear velocity $u_{*}$ defined from $\tau_{0}=\rho u_{*}^{2}$, which defines the shear velocity $u_{*}$ from $u_{*}=\left(g R S_{f}\right)^{1 / 2}$.

There are three basic approaches to evaluate channel roughness without vegetation: (1) the Darcy-Weisbach friction factor $f\left[V=(8 / f)^{1 / 2}\left(g R S_{f}\right)^{1 / 2}\right]$; (2) the Manning resistance coefficient $n\left[V=(1 / n)\left(R^{2 / 3} S_{f}^{1 / 2}\right)\right]$; and (3) the Chézy conveyance coefficient $C\left[V=C\left(R S_{f}\right)^{1 / 2}\right]$, where $V$ is the cross-section averaged velocity and $R$ is the hydraulic radius and $S_{f}$ is the friction slope. Both $f$ and $n$ describe resistance to flow, while $C$ describes flow conveyance. It is also interesting to note that only $f$ is dimensionless, while $C=L^{1 / 2} / T$ and $n=T / L^{1 / 3}$. Manning $n$ values were calculated for various flow discharges in representative study reaches. In this study, values of DarcyWeisbach $f$ and Chézy $C$ were then computed from Manning $n$ using $f=8 g\left(n / R^{1 / 6}\right)^{2}$ and $C=R^{1 / 6} / n$, respectively [11].

\subsection{Vegetation Roughness Coefficients}

The determination of vegetation roughness coefficients has been somewhat of an art resulting from a vast experience dealing with theoretical advances in turbulence, experimental laboratory studies and empirical field measurements on rivers and streams since the compilation by Chow [7]. Roughness values for flood plains can be quite different from the values for the main channels; therefore, roughness values for flood plains should be determined independently from channel values. As in the computation of channel roughness, a base roughness is assigned to the flood plain, and adjustments for various roughness factors are made to determine the total Manning $n$ value for the flood plain. Although much research has been done on Manning's roughness coefficient, relatively less has been done concerning the roughness values for densely vegetated flood plains. The $n$ value is determined from the values of the factors that affect the roughness of channels and flood plains. In densely vegetated flood plains, the major roughness is caused by trees, grasses, and shrubs [10]. For a wooded flood plain, the vegetation-density method can be used as an alternative to the previous method for determining $n$ values for flood plains. In a wooded flood plain, where the tree 
diameters can be measured, the vegetation density of the flood plain can be determined.

In South Korea, the values for Manning $n$ for flood plains can be determined by measuring the vegetation density of the flood plain [15]. Specific procedures can be used to determine the values for roughness coefficients in channels and flood plains. Manning $n$ values for channels are determined by evaluating the effects of certain roughness factors in the channels. Two methods are available to determine the roughness coefficients of flood plains. One method, similar to that for channel roughness, involves the evaluation of the effects of certain roughness factors in the flood plain. The other method involves the evaluation of the vegetation density of the flood plain to determine the Manning $n$ value. This second method is particularly suited to handle roughness for densely wooded flood plains.

\subsection{MOCT Method}

In South Korea, the analysis of flow in vegetated channels follows the method of the Ministry of Construction and Transportation and KICT [13]. The MOCT method was applied in this study. The approach is based on with vegetation in number of flow cross section and with vegetation only one side flood plain. The average flow velocity is calculated from $V=(8 / f)^{1 / 2}\left(g R S_{f}\right)^{1 / 2}$ given the roughness coefficients due to channel friction with vegetation given as $f=\lambda+4 c \omega R$ in this study, where $\lambda=$ friction factor in bed or slope side, $c=$ friction constant due to vegetation (1.0-1.5), $\omega=$ vegetation type in area per volume $\left(\mathrm{m}^{-1}\right)$ for grasses $=0.1-1.5$, shrubs $=1.5-3.0$, trees (detailed below) where $d=$ tree diameter, $a_{x}, a_{y}=$ distance between trees in $x, y$ direction, respectively. The average flow velocity in vegetated channels is thus calculated from

$$
V=\sqrt{\frac{8 g R S_{f}}{\lambda+4 c \omega R}}
$$

Manning $n$ in this study is then calculated by the MOCT method with the Chézy friction factor from Eq. (3) including the roughness from the River Vegetation Patterns (RVP) as shown in Fig. 2. The parameters in this flow chart are: $A_{f}=$ cross-section area of flood plain, $b_{f}=$ effect width due to vegetation calculated vortex flow width $b_{N}=3.2\left(a_{y} d\right)^{1 / 2}$ as a function of diameter $d$ and distance between tree $a_{y}, b_{m}=$ averaged width of cross-section without vegetation, $P_{f}=$ wetted perimeter of flood plain $(\mathrm{m}), R_{f}=$ hydraulic radius of flood plain $\left(=A_{f}\left(P_{f}\right), R_{m}=\right.$ assumed hydraulic radius in order to calculate the initial friction factor $\lambda_{m}, V_{f}=$ flood plain velocity with vegetation, $V_{m}=$ main channel velocity not considering a separated flood plain, $\lambda_{f}=$ friction factor due to vortex flow with a separated flood plain. Also, $\lambda_{m}=$ friction factor determined by trial and error until approximately equal to $\lambda_{f}$ from the assumed initial $R_{m}, \lambda_{M T}$ and $V_{M T}=$ friction factor and averaged velocity for total cross-section area with vegetation, respectively. The roughness coefficient is the $n$ converted into a Manning $n$ to simulate by the HEC-RAS and RMA-2 models.

\subsection{Numerical Models}

The calculation of flood levels with and without vegetation is carried out with the 1-D numerical model HEC-RAS [26] and with the 2-D model RMA-2 [5], respectively. These two models were selected because they are representative of frequently used 1-D and 2-D models. HEC-RAS is used as a standard method in the United States, and elsewhere. The RMA-2 model has been selected here for comparison with 1-D modeling results.

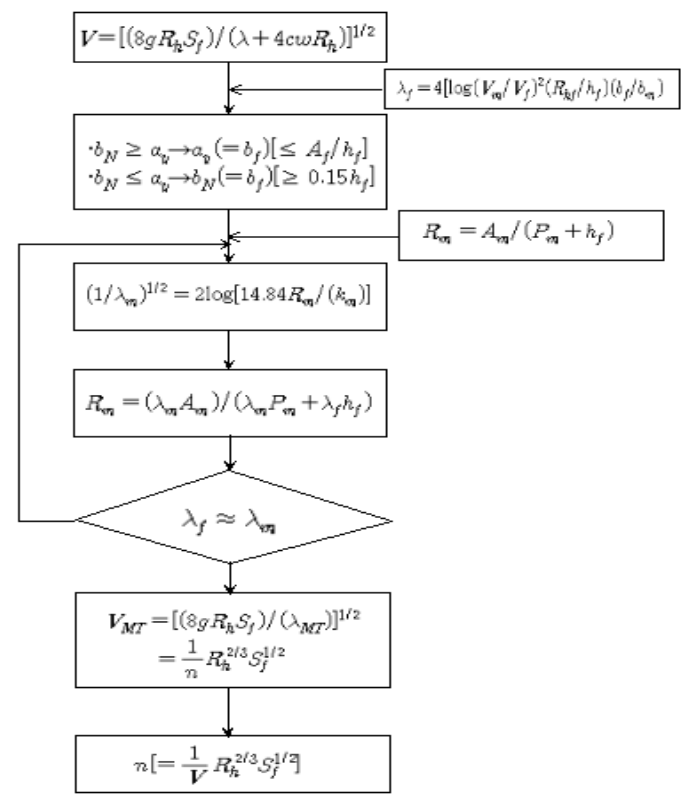

Fig. 2. Flow Chart for Calculation of Vegetation Density in the RVP

2.5.1 One-dimensional model HEC-RAS: HEC-RAS is a hydraulic model developed by the Hydrologic Engineering Center (HEC) of the U.S. Army Corps of Engineers [26]. The system is capable of modeling subcritical, supercritical, and mixed-flow regimes for streams consisting of a full network of channels, a dendritic system, or a single river reach. The model results are routinely applied in floodplain management and flood insurance studies in order to evaluate the effects of floodway encroachments. At each cross-section, HEC-RAS uses several input parameters to describe shape, elevation, and relative location along the stream. River stations (cross-section) number, lateral and elevation coordinates for each (dry, unflooded) terrain point are also required as well as left and right bank station locations. Reach lengths between the left floodway, stream centerline, and right floodway of adjacent cross-sections represent the main three reach segments of a cross section. For steady and gradually varied flow, the primary procedure for computing water surface profiles between crosssections is called the direct step method (HEC-RAS also supports the momentum, WSPRO bridge, and Yarnell methods). The basic computational procedure is based on the iterative solution of the energy equation.

Many field investigations on the validation of HEC-RAS have been presented in the recent literature: Brunner [3] on hydraulic reference manual for river analysis system; Ackerman et al. [1] about new floodplain delineation capabilities in HEC-RAS; Stevenson [23] on 1-D HEC-RAS model and sensitivity analysis for St. Clair River from 1971- 
2007; Mashriqui and Aschwanden [18] on toward modeling of river-estuary-ocean interactions to enhance operational river forecasting in the NOAA National Weather Service; Timbadiya et al. [25] about calibration of HEC-RAS model on prediction of flood for lower Tapi River, India, respectively.

2.5.2 Two-dimensional model RMA-2: The Surface Water Modeling System (SMS) is a comprehensive computational software package for 1D, 2D, and 3D hydrodynamic modeling[5]. The numerical models supported in SMS-2D compute a variety of information applicable to surface water modeling. Primary applications of the models include calculation of water surface elevations and flow velocities for shallow water flow problems, for both steady-state or dynamic conditions. New enhancements and developments continue at the Environmental Modeling Research Laboratory (EMRL) at Brigham Young University in cooperation with the U.S. Army Corps of Engineers Waterways Experiment Station (USACEWES), and the US Federal Highway Administration (FHWA). Analysis results from any of the models in SMS can be output or displayed graphically using a variety of plots, including vector plots, contour plots, color-shaded contour plots, and time-history plots. Contour plots and color-shaded contour plots of water surface elevation, velocity, discharge, contaminant concentration, and bed scour and deposition can easily be generated for any of the computed time-steps. It has also been frequently applied to engineering designs projects for bank protection and grade-control structures which must extended below the potential channel bed scour and withstand the design flood.

Applications of the 2D-model RMA-2 have been presented such as Gee et al. [9] on 2-D floodplain modeling; Swindon et al. [24] about ungauged watershed modeling-utilization of hydraulic models for validation; Wagner and Mueller [27] on calibration and validation of a 2-D hydrodynamic model of the Ohio River; Bruxer and Thompson [4] about St. Clair River hydrodynamic modeling using RMA-2, respectively.

Both models have been also used in South Korea. For instance, Park et al. [20] have used both models for applications on the Lower Nakdong River in a recent report for K-Water on the Improvement of Maintenance Enhancement Methods for the Nakdong River Estuary Barrage. The selected models are therefore appropriate for the analysis of river restoration problems.

\section{STUDY SITES FOR RIVER RESTORATION}

Rivers in South Korea are classified as large, medium, or small depending on the design flood discharge $Q_{D}$ in $\mathrm{m}^{3} / \mathrm{s}$ and the drainage area $A_{r}$ in $\mathrm{km}^{2}$ as shown in Table 3 [17], [19].

Table 3. South Korean River Classification

\begin{tabular}{|c|c|c|c|}
\hline $\begin{array}{l}\text { River } \\
\text { type }\end{array}$ & $\begin{array}{l}\text { Design flood discharge } \\
\qquad Q_{D}\left(\mathrm{~m}^{3} / \mathrm{s}\right)\end{array}$ & $\begin{array}{c}\text { Drainage area } \\
\left(\mathrm{km}^{2}\right)\end{array}$ & Remarks \\
\hline Large & $Q_{D}>10,000$ & $A_{r}>1,000$ & \multirow{3}{*}{$\begin{array}{l}Q_{D}=\text { Design flood } \\
\text { discharge } \\
\cdot A_{r}=\text { Drainage area }\end{array}$} \\
\hline Medium & $5,000<Q_{D} \leq 10,000$ & $10<A_{r} \leq 1,000$ & \\
\hline Small & $Q_{D} \leq 5,000$ & $1<A_{r} \leq 10$ & \\
\hline
\end{tabular}

\subsection{Description of the Three Field Study Sites}

Three reference river reaches (one large, one medium and one small) of the Geum River were selected for this study. The location map of the study sites is shown in Fig. 3 and a brief summary of the main river characteristics is presented in Table 4.
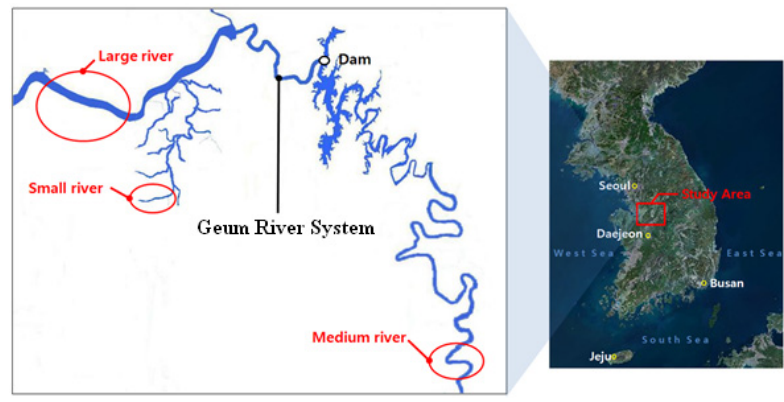

Fig. 3. Study Site in Geum River System

Table 4. Summary of Hydraulic Geometry of the Three Field Study Sites

\begin{tabular}{c|c|c|c|c|c|c}
\hline \multirow{2}{*}{$\begin{array}{c}\text { River } \\
\text { type }\end{array}$} & Station & \multirow{2}{*}{\begin{tabular}{c} 
Reach \\
length \\
\cline { 5 - 7 }
\end{tabular}} & & \multicolumn{2}{|c|}{ Normal level } & \multicolumn{2}{|c}{ Flood level } \\
\cline { 5 - 7 } & & $\begin{array}{c}\text { Width } \\
(\mathrm{m})\end{array}$ & $\begin{array}{c}\text { Depth } \\
(\mathrm{m})\end{array}$ & $\begin{array}{c}\text { Width } \\
(\mathrm{m})\end{array}$ & $\begin{array}{c}\text { Depth } \\
(\mathrm{m})\end{array}$ \\
\hline Large & $\begin{array}{c}\text { Chungnam } \\
\text { Gongju }\end{array}$ & 3,000 & 250 & 3 & 420 & 15 \\
\hline Medium & $\begin{array}{c}\text { Chungbuk } \\
\text { Youngdong }\end{array}$ & 1,000 & 80 & 1 & 210 & 7 \\
\hline Small & $\begin{array}{c}\text { Chungnam } \\
\text { Gongju }\end{array}$ & 200 & 6 & 0.3 & 22 & 2.2 \\
\hline
\end{tabular}

\subsection{Large River Study Site}

Fig. 4 illustrates the field study conditions for the large river site near Chungnam Gongju on the Geum River basin. A photo of the site (Fig. 4a) is complemented with an aerial photo (Fig. $4 b)$ of the field study site.

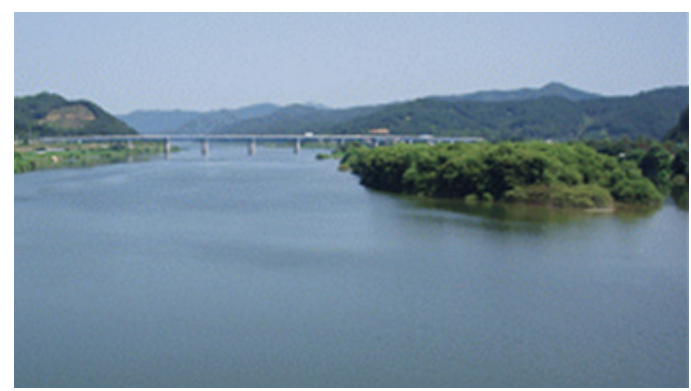

(a) Large river study site

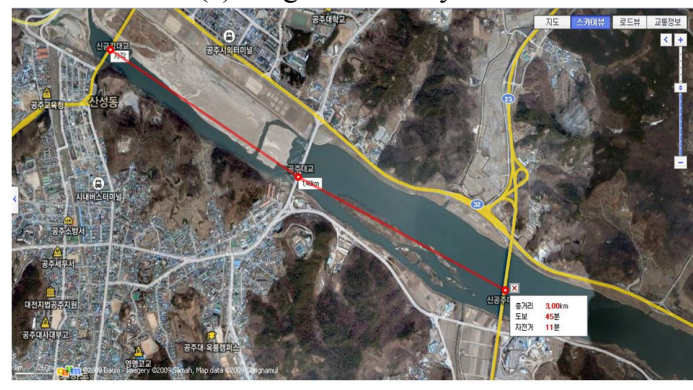

(b) Aerial photo

Fig. 4. Field Conditions of the Large River Study Site on the Geum River 


\subsection{Medium River Study Site}

Fig. 5 illustrates the field study conditions for the medium river study site near Chungbuk Youngdong on the Geum River basin. A photo of the site (Fig. 5a) is complemented with an aerial photo (Fig. 5b) of the field study site.

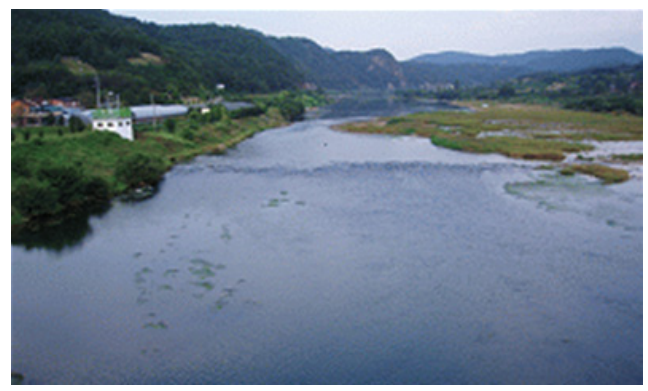

(a) Medium river study site

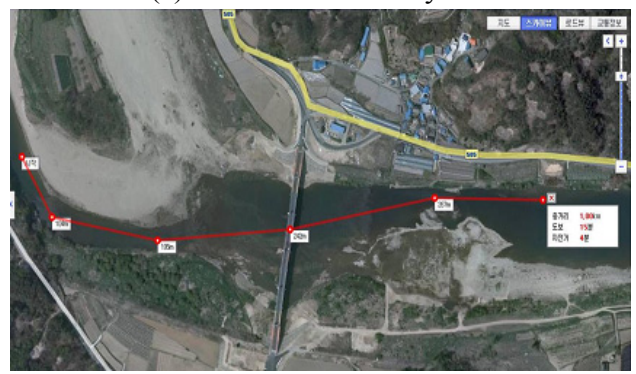

(b) Aerial photo

Fig. 5. Field Conditions of the Medium River Study Site on the Geum River

\subsection{Small River Study Site}

Fig. 6 illustrates the field study conditions for the small river study site near Yongsu stream of the Geum River basin. A photo of the site (Fig. 6a) is complemented with an aerial photo (Fig. 6b) of the field study site.

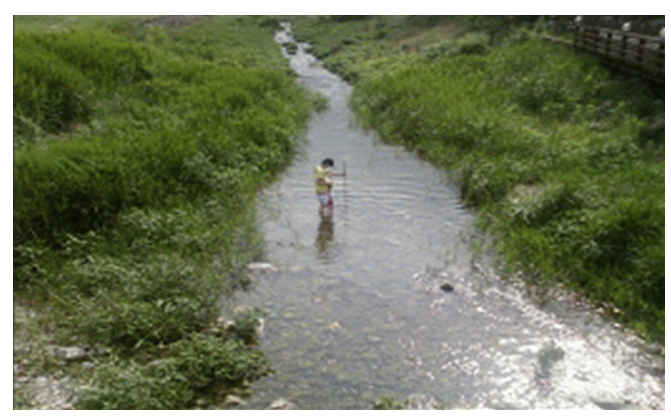

(a) Small river study site

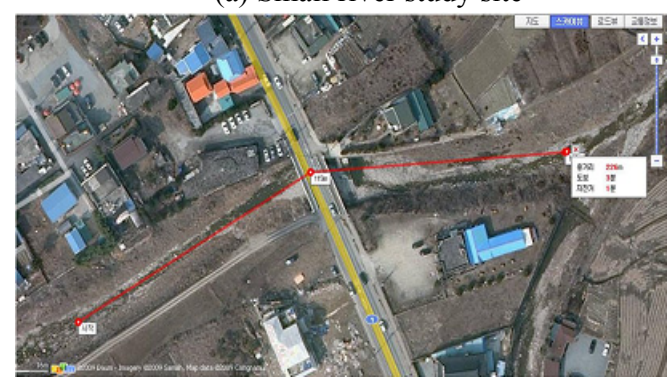

(b) Aerial photo

Fig. 6. Field Conditions of the Small River Study Site on the Geum River

\subsection{River Vegetation Patterns for River Restoration}

A study of River Vegetation Patterns (RVP) for the restoration of the three sites is shown in Fig. 7 [19]. Different vegetation patterns are being considered for the three different sites. On the large river in Fig. 7(a) the RVP is composed trees, shrubs and grasses, including Salix gracilityla Miq., Salix integra Thunb., and tree species of Salix koreensis, Salix grandulosa, Salix nipponica.

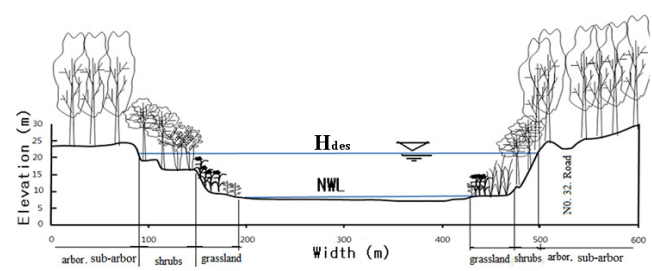

(a) Large river

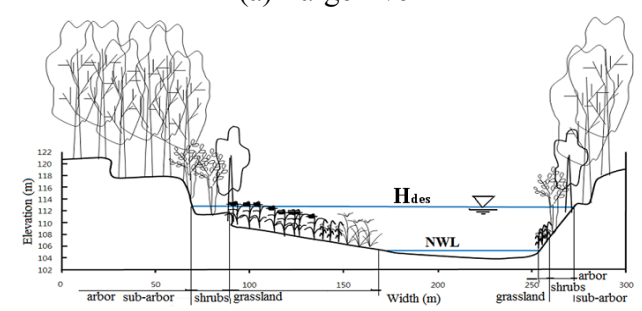

(b) Medium river

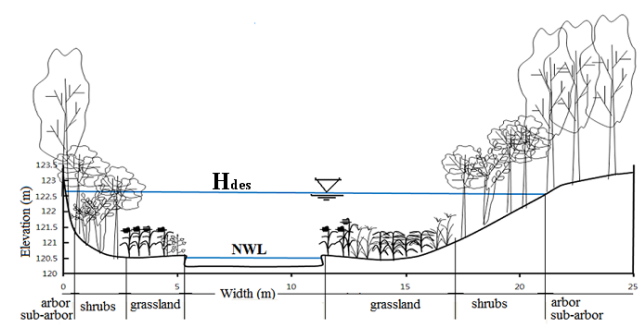

(c) Small river

Fig. 7. RVP for the Restoration of the Three Study Sites

Vegetation for the medium river shown in Fig. 7(b) includes grasses and shrubs including primarily Salix integra Thunb., Rosa multiflora, and some sub-arbor and arbor species of Salix koreensis, Acer ginnale Maxim., respectively. In the case of the small river, Fig. 7(c) shows the RVP grassland and shrubs including primarily Salix gracilityla Miq., Rosa multiflora, and tree species like Salix koreensis, Acer ginnale Maxim., Morus bombycis Koidz. The vegetation density from these RVP has also been investigated. Table 5 summarizes typical characteristics of the number and size of shrubs and trees for the three river types.

Table 5. Vegetation Density per Number and Size of Shrubs and Trees for the Three River Types

\begin{tabular}{|c|c|c|c|}
\hline \multirow{2}{*}{\multicolumn{2}{|c|}{ River type }} & \multicolumn{2}{|c|}{ Vegetation density per $100 \mathrm{~m}^{2}$} \\
\hline & & \multirow{2}{*}{$\begin{array}{c}\text { Shrubs } \\
2.4\end{array}$} & \multirow{2}{*}{$\begin{array}{c}\text { Trees } \\
0.88\end{array}$} \\
\hline \multirow{2}{*}{ Large } & Tree number(-) & & \\
\hline & Mean dia.(m) & 0.080 & 0.138 \\
\hline \multirow{2}{*}{ Medium } & Tree number(-) & 2.6 & 1.1 \\
\hline & Mean dia.(m) & 0.080 & 0.199 \\
\hline \multirow{2}{*}{ Small } & Tree number(-) & 2.0 & 1.4 \\
\hline & Mean dia.(m) & 0.067 & 0.147 \\
\hline
\end{tabular}




\section{MODEL APPLICATIONS AND SIMULATION RESULTS}

The application of the concept of Vegetation Freeboard Equivalence has been carried out by comparing 1-D HEC-RAS and 2-D RMA-2 simulation for the large, medium and small rivers.

\subsection{HEC-RAS Simulation Results}

The hydraulic characteristics for each station and cross section were used for the HEC-RAS simulation of the large, medium and small rivers respectively. A summary of the mean conditions for the HEC-RAS simulations without vegetation is shown in Table 6. The hydraulic conditions to calculate for flood stage in large, medium and small rivers using HEC-RAS are also summarized in Table 7 and the results with vegetation are also shown in Fig. 8.

Table 6. HEC-RAS Simulation Conditions without Vegetation for the Three River Types

\begin{tabular}{c|c|c|c}
\hline Boundary conditions & Large river & Medium river & Small river \\
\hline $\begin{array}{c}\text { Design flood discharge } \\
Q_{D}\left(\mathrm{~m}^{3} / \mathrm{s}\right)\end{array}$ & $\begin{array}{c}11,800 \\
(200 \mathrm{yr})\end{array}$ & $\begin{array}{c}3,960 \\
(150 \mathrm{yr})\end{array}$ & $\begin{array}{c}195 \\
(100 \mathrm{yr})\end{array}$ \\
\hline $\begin{array}{c}\text { Design flood stage } \\
H_{\text {des }}(\text { EL.m) }\end{array}$ & 19.18 & 112.10 & 122.82 \\
\hline Bed slope $S_{f}{ }^{\prime}(\mathrm{m} / \mathrm{m})$ & $1 / 5,000$ & $1 / 1,191$ & $1 / 245$ \\
\hline Manning $n$ coefficient & 0.027 & 0.032 & 0.032 \\
\hline
\end{tabular}

Table 7. Comparison of Hydraulic Conditions with and without Vegetation during Floods Using HEC-RAS

\begin{tabular}{l|c|c|c|c|c|c|c}
\hline \multirow{2}{*}{$\begin{array}{l}\text { Hydraulic } \\
\text { conditions }\end{array}$} & \multicolumn{3}{|c|}{ Without vegetation } & \multicolumn{3}{c}{ With vegetation } \\
\cline { 2 - 8 } & Left & Main & Right & Left & Main & Right \\
\hline \multirow{3}{*}{$\begin{array}{l}\text { Roug. } \\
\text { Coef.f }\end{array}$} & L & 0.027 & 0.027 & 0.027 & 0.050 & 0.027 & 0.068 \\
\cline { 2 - 8 } & $\mathrm{M}$ & 0.032 & 0.032 & 0.032 & 0.0538 & 0.032 & 0.0494 \\
\cline { 2 - 8 } & $\mathrm{S}$ & 0.032 & 0.032 & 0.032 & 0.038 & 0.032 & 0.037 \\
\hline \multirow{3}{*}{$\begin{array}{l}\text { Area } \\
\left(\mathrm{m}^{2}\right)\end{array}$} & $\mathrm{L}$ & 117.97 & 3791.27 & 111.68 & 144.85 & 3948.31 & 122.44 \\
\cline { 2 - 8 } & $\mathrm{M}$ & 136.80 & $1,289.84$ & 130.58 & 131.50 & $1,271.55$ & 126.74 \\
\cline { 2 - 8 } & $\mathrm{S}$ & 11.81 & 17.22 & 19.25 & 12.51 & 18.01 & 20.61 \\
\hline \multirow{2}{*}{$\begin{array}{l}\text { Mean } \\
\text { vekcity } \\
(\mathrm{m} / \mathrm{s})\end{array}$} & $\mathrm{L}$ & 0.97 & 3.03 & 1.67 & 0.46 & 2.96 & 0.53 \\
\cline { 2 - 8 } & $\mathrm{M}$ & 1.39 & 2.75 & 1.68 & 0.58 & 2.98 & 0.78 \\
\cline { 2 - 8 } & $\mathrm{S}$ & 3.64 & 4.78 & 3.63 & 2.61 & 4.99 & 2.64 \\
\hline \multirow{2}{*}{$\begin{array}{l}\text { Disch. } \\
\left(\mathrm{m}^{3} / \mathrm{s}\right)\end{array}$} & $\mathrm{L}$ & 114 & 11,488 & 186 & 67 & 11,687 & 65 \\
\cline { 2 - 8 } & $\mathrm{M}$ & 190 & 3,547 & 219 & 76 & 3,789 & 99 \\
\cline { 2 - 8 } & $\mathrm{S}$ & 43 & 82 & 69 & 33 & 90 & 54 \\
\hline
\end{tabular}
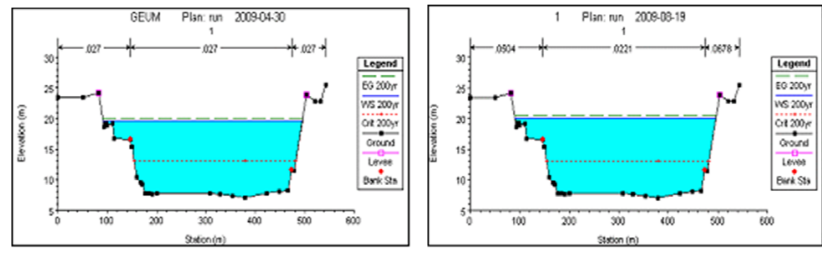

(a) Large river

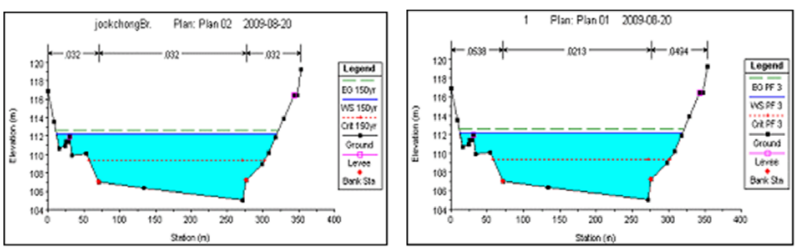

(b) Medium river
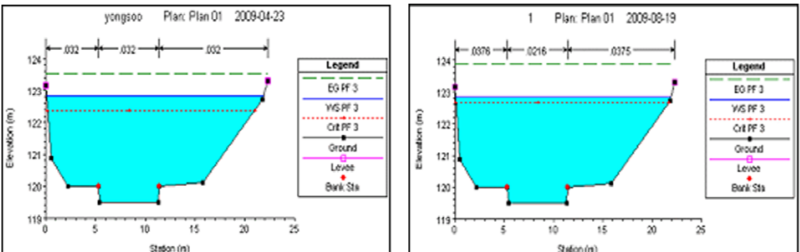

(c) Small river

(1) Without vegetation

(2) With vegetation

Fig. 8. Comparison of Flood Stages Calculated with RVP

Using HEC-RAS

\subsection{RMA-2 Simulation Results}

The main characteristics of the RMA-2 mesh network and element scale for the two-dimensional simulation of flood stages during floods with vegetation are listed in Table 8 . The calculated velocity profiles with and without vegetation and the water surface elevation profiles are shown in Fig. 9 for the three river types, respectively.

Table 8. Mesh Size Characteristics and Boundary Conditions for the RMA-2 Simulations

\begin{tabular}{|c|c|c|c|c|c|c|c|c|}
\hline \multirow[b]{2}{*}{ Riv } & \multirow[b]{2}{*}{$\begin{array}{c}\text { Node } \\
\text { No. }\end{array}$} & \multirow[b]{2}{*}{$\begin{array}{c}\text { Elem. } \\
\text { Scale } \\
(\mathrm{m})\end{array}$} & \multicolumn{3}{|c|}{ Elements } & \multicolumn{3}{|c|}{ Boundary conditions } \\
\hline & & & Rec. & Tri. & Total & $\begin{array}{l}\text { T. D. } \\
\text { Coef. } \\
\text { (Nsmin') }\end{array}$ & $\begin{array}{l}\text { Dis. } \\
\left(\mathrm{m}^{3} / \mathrm{s}\right)\end{array}$ & $\begin{array}{l}\text { W.L. } \\
\text { (ELm) }\end{array}$ \\
\hline $\mathrm{L}$ & 12,041 & $20 \times 20$ & 3,622 & 412 & 4,034 & 1,500 & 11,800 & 19.18 \\
\hline M & 3,966 & $20 \times 20$ & 1,158 & 155 & 1,313 & 1,000 & 3,960 & 112.10 \\
\hline$S$ & 1,858 & $3 \times 3$ & 575 & 1 & 576 & 1,000 & 195 & 122.82 \\
\hline
\end{tabular}

From RMA-2, the mean flow velocity with and without vegetation are shown to increase by $2 \sim 15 \%$ in the main channel with a corresponding decrease by $8 \sim 27 \%$ on the overbank flows. The main results are summarized in Table 9 for the large, medium, and small river. It is important to notice that vegetation primarily decreases the flow velocity on the floodplain an increases velocity in the main channels. The effects are more pronounced in large rivers than in small rivers.
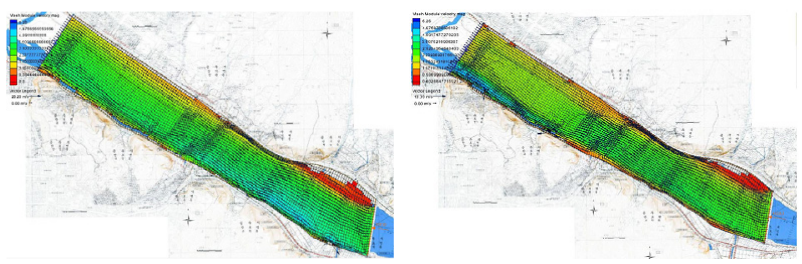

(a) Large river

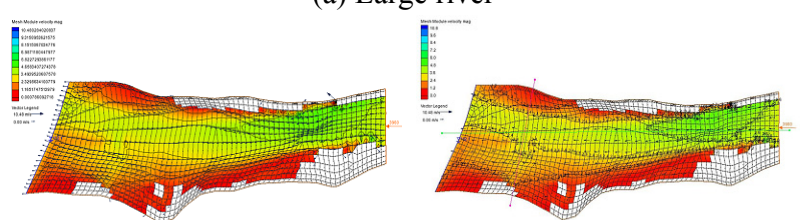

(b) Medium river 

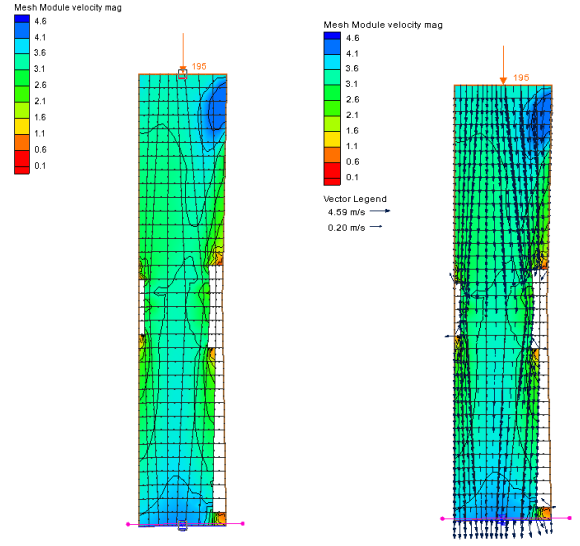

(c) Small river

(1) Without vegetation

(2) With vegetation

Fig. 9. Profiles of Velocity Calculated by RMA-2

Table 9. Comparisons of Mean Velocity Calculated by RMA-2 in RVP

\begin{tabular}{c|c|c|c|c|c|c}
\hline \multirow{2}{*}{$\begin{array}{c}\text { River } \\
\text { type }\end{array}$} & \multicolumn{3}{|c|}{ Main channel } & \multicolumn{3}{c}{ Left and right channel } \\
\cline { 2 - 7 } & WO veg. & W veg. & Var. & WO Veg. & W Veg. & Var. \\
\hline Large & $2.78 \mathrm{~m} / \mathrm{s}$ & $3.21 \mathrm{~m} / \mathrm{s}$ & $+15 \%$ & $2.67 \mathrm{~m} / \mathrm{s}$ & $1.95 \mathrm{~m} / \mathrm{s}$ & $-27 \%$ \\
\hline Med. & $3.04 \mathrm{~m} / \mathrm{s}$ & $3.21 \mathrm{~m} / \mathrm{s}$ & $+8 \%$ & $1.46 \mathrm{~m} / \mathrm{s}$ & $1.01 \mathrm{~m} / \mathrm{s}$ & $-25 \%$ \\
\hline Small & $3.23 \mathrm{~m} / \mathrm{s}$ & $3.29 \mathrm{~m} / \mathrm{s}$ & $+2 \%$ & $3.27 \mathrm{~m} / \mathrm{s}$ & $3.01 \mathrm{~m} / \mathrm{s}$ & $-8 \%$ \\
\hline
\end{tabular}

\subsection{VFE Analysis}

Table 10 shows the applicability of the Vegetation Freeboard Equivalence concept to three types of rivers studied in this article. In the case with vegetation, the freeboard height is adequate for the large river. However, the levees would need to be raised for the medium and the small rivers. The results without vegetation are quite similar between the two models HEC-RAS and RMA-2. However in presence of vegetation, the differences between the two models become more pronounced, and this is particularly true for the medium and small rivers.

Table 10. Evaluation of the Levels with Vegetation Density for the Three Sites Studied

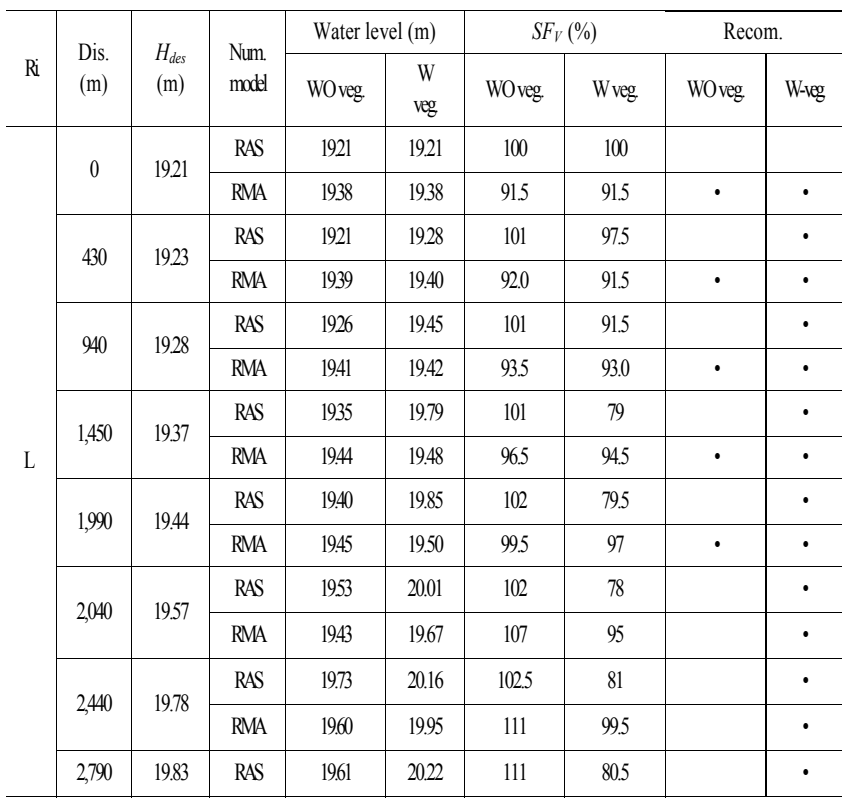

\begin{tabular}{|c|c|c|c|c|c|c|c|c|c|}
\hline & & & RMA & 19.60 & 19.95 & 111.5 & 94 & & - \\
\hline \multirow{14}{*}{ M } & \multirow{2}{*}{0} & \multirow{2}{*}{112.10} & RAS & 112.10 & 11232 & 100 & 81.67 & & - \\
\hline & & & RMA & 112.10 & 112.10 & 100 & 100 & & \\
\hline & \multirow{2}{*}{180} & \multirow{2}{*}{112.10} & RAS & 112.07 & 112.45 & 1025 & 70.83 & & - \\
\hline & & & RMA & 112.13 & 112.22 & 97.50 & 90 & . & - \\
\hline & \multirow{2}{*}{350} & \multirow{2}{*}{112.11} & RAS & 112.17 & 112.53 & 95 & 65.00 & - & $\cdot$ \\
\hline & & & RMA & 112.20 & 112.41 & 92.50 & 75 & . & . \\
\hline & \multirow{2}{*}{570} & \multirow{2}{*}{11237} & RAS & 112.26 & 112.66 & 109.17 & 75.83 & & $\cdot$ \\
\hline & & & RMA & 11238 & 11253 & 99.17 & 86.67 & . & $\cdot$ \\
\hline & \multirow{2}{*}{860} & \multirow{2}{*}{112.51} & RAS & 11234 & 112.87 & 114.17 & 70.00 & & $\cdot$ \\
\hline & & & RMA & 11252 & 112.61 & 99.17 & 91.67 & . & $\cdot$ \\
\hline & \multirow{2}{*}{1020} & \multirow{2}{*}{112.53} & RAS & 112.59 & 113.26 & 95 & 39.17 & . & • \\
\hline & & & RMA & 112.55 & 112.74 & 98.33 & 82.50 & $\cdot$ & $\cdot$ \\
\hline & \multirow{2}{*}{1,220} & \multirow{2}{*}{112.67} & RAS & 112.76 & 113.52 & 925 & 29.17 & . & $\bullet$ \\
\hline & & & RMA & 112.72 & 112.89 & 95.83 & 81.67 & . & $\cdot$ \\
\hline \multirow{6}{*}{ S } & \multirow{2}{*}{0} & \multirow{2}{*}{122,82} & RAS & 122.82 & 123.10 & 100 & 5333 & & . \\
\hline & & & RMA & 122.82 & 122.82 & 100 & 100 & & \\
\hline & \multirow{2}{*}{50} & \multirow{2}{*}{122.82} & RAS & 12339 & 123.21 & 21.67 & 35.00 & • & $\bullet$ \\
\hline & & & RMA & 123.08 & 123.18 & 56.67 & 40 & . & $\bullet$ \\
\hline & \multirow{2}{*}{100} & \multirow{2}{*}{122.82} & RAS & 123.00 & 123.63 & 70 & -35.00 & . & $\infty$ \\
\hline & & & RMA & 123.10 & 123.22 & 53.33 & 33.33 & . & • \\
\hline
\end{tabular}

\section{CONCLUSIONS}

The concept of vegetation freeboard equivalence (VFE) is detailed in this article. The rise in flood stage from the added vegetation is compared with the freeboard height under design flood discharge conditions. Three rivers in South Korea have been modeled with and without vegetation using the 1-D model HEC-RAS and the 2-D model RMA-2. The vegetation safety factor is defined from the $V F E$ for each of the three reaches of the large, medium and small river selected for the study analysis. The main conclusions of this study are:

1. All models show that floodplain velocity decreases and channel flow velocity increases when adding floodplain vegetation.

2. Without vegetation, both models HEC-RAS and RMA-2 adequately predict the flood stages of the large and medium river. The small river is however more subject to spatial variability in flood stage levels.

3. The effects of vegetation on freeboard height are most important in small river systems. The vegetation effects on the medium river are less significant, and the freeboard is adequate to contain the rise in stage from the added floodplain vegetation in large rivers.

Note that these conclusions may not be universally applicable to all large, medium and small rivers. However, the novel VFE approach described in this paper with HEC-RAS and/or RMA2 may be very useful in river restoration projects.

\section{REFERENCES}

[1] T.C. Ackerman, M.R. Jensen and G.W. Brunner, "New floodplain delineation capabilities in HEC-RAS," Proc. ASCE, 2009, p. 1-7. 
[2] H.H. Barnes, Roughness characteristics in natural channels, USGS, Washington, 1967.

[3] G.W. Brunner, HEC-RAS, River analysis system hydraulic reference manual, USACE, HEC, 2008.

[4] J. Bruxer and A. Thompson, St. Clair River hydrodynamic modelling using RMA2 Phase 1 Report, IUGLS SCRTT, Canada, 2008.

[5] BYU (Brigham Young University), The surface-water modeling system (SMS)(Ver 9.2) tutorials manual, BYU, EMRL, 2006.

[6] S.U. Choi and J. Shin, "Prediction of stage in a stream with vegetation on the floodplain," $W W F$, Incheon, 2009.

[7] V.T. Chow, Open Channel Hydraulics, McGraw-Hill, 1959.

[8] S.E. Darby, "Modeling effect of riparian vegetation on flow resistance and flood potential," ASCE Journal, vol. 125, no. 5, 1999, pp. 443-454.

[9] D.M. Gee, M.G. Anderson and L. Baird, Twodimensional floodplain modeling, USACE, IWHEC, Davis, 1990.

[10] P.Y. Julien, River Mechanics. Cambridge University Press, New York, 2002.

[11] P.Y. Julien, Erosion and Sedimentation. $2^{\text {nd }}$ Edition, Cambridge University Press, New York, 2010.

[12] F. Karim, "Bed configuration and hydraulic resistance in alluvial-channel flows," ASCE Journal, vol. 121, no. 1, 1995 , pp. $15-25$.

[13] KICT (Korea Institutive of Construction Technology), Technology development for trees management in flood plain, KICT, Seoul, 2007, p. 47-76 (in Korean).

[14] N. Kouwen and R.M. Li, "Biomechanics of vegetative channel linings," ASCE Journal, vol. 106, no. 6, 1980, pp. 1085-1103.

[15] KWRA (Korea Water Resource Association), River design criteria and explanation, KWRA, Seoul, 2009 (in Korean).

[16] J.S. Lee, River Engineering and Design. SaeRon Publish Inc., Seoul, 2010(in Korean).

[17] J.S. Lee and B.C. Kim, "Flood stage evaluation for vegetated models in river scales," KSCE Journal, vol. 30, no. 5B, 2010, pp. 509-518 (in Korean).

[18] H. Mashriqui, S. Reed and C. Aschwanden, "Toward modeling of river-estuary-ocean interactions to enhance operational river forecasting in the NOAA National Weather Service," Conference JFI, 2010.

[19] MOCT (Ministry of Construction and Transportation), Development of application and management method, river alignment and evaluation-Evaluation hydraulic stability, MOCT, Seoul, 2009(in Korean).

[20] S.K. Park et al., Improvement of maintenance enhancement methods for the Nakdong River estuary barrage, BRO K-Water, 2008(in Korean).

[21] Y.H. Shin and P.Y. Julien, "Changes in hydraulic geometry downstream of Hapcheon re-regulation dam, South Korea," IRBM Journal, vol. 8, no. 2, 2010, pp. 139-150.

[22] J.G. Song, B.C. Kim and J.S. Lee, "Evaluation of hydraulic stability for river with vegetation," Proc. KWRA, 2010, pp. 855-859 (in Korean).
[23] D. Stevenson, 1-D HEC-RAS Model and Sensitivity Analysis for St. Clair River from 1971-2007, IJCI UGLS, Ottawa, 2009.

[24] L.B. Swindon, D.N. Gee and M.G. Andeson, "Ungauged catchment modelling II. Utilization of Hydraulic models for validation," CATENA, SSHG Journal, vol. 19, 1992, pp. 33-42.

[25] P.V. Timbadiya, P.L. Patel and P.D. Porey, "Calibration of HEC-RAS model on prediction of flood for lower Tapi River, India,” WRP Journal, vol. 3, 2011, pp. 805-811.

[26] USACE (U.S. Army Corps of Engineers), HEC-RAS (River Analysis System) Application guide (Ver. 4.1), USAC, Davis, 2010.

[27] C.R. Wagner and D.S. Mueller, Calibration and validation of a two-dimensional hydrodynamic model of the Ohio River, USGS, Denver, 2001.

[28] H.S. Woo et al., "Hydraulic resistance of some selected vegetation in open channel flows," RRA Journal, vol. 24, 2008, pp. 673-687.

[29] F.C. Wu, H.W. Shen and Y.J. Chou, "Variation of roughness coefficients for unsubmerged and submerged vegetation," ASCE Journal, vol. 125, no. 9, 1999, pp. 934-942.

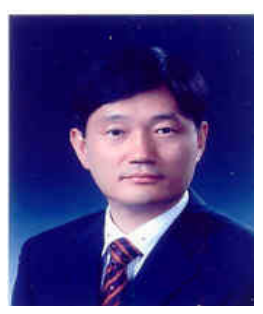

Jong-Seok Lee

He received the B.S., M.S., and Ph.D. in civil engineering from Dankook university, Korea in 1987, 1989 and 1995, respectively. Since then, he has been a professor of Civil Engineering department at Hanbat National University in Korea. His main research interests include hydraulic, hydrology, sedimentation, and river engineering.

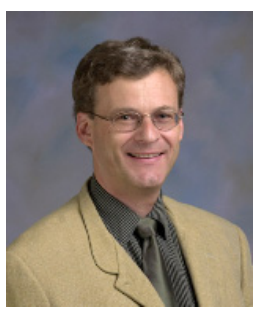

Pierre Y. Julien

He received the B.S., M.S, and Ph.D. in civil engineering from Laval university, Canada in 1977, 1980 and 1983, respectively. Since then, he has been a professor of Civil Engineering department at Colorado State University in USA. His main research interests include hydraulic engineering, river mechanics, and erosion and sedimentation. 